DOI: https://doi.org/10.17816/ecogen54703

\title{
Unique transcriptome features of pea (Pisum sativum L.) lines with differing responses to beneficial soil microorganisms
}

\author{
(C) Alexey M. Afonin, Emma S. Gribchenko, Evgeny A. Zorin, Anton S. Sulima, Daria A. Romanyuk, \\ Aleksandr I. Zhernakov, Oksana Yu. Shtark, Gulnar A. Akhtemova, Vladimir A. Zhukov \\ All-Russia Research Institute for Agricultural Microbiology, Pushkin, Saint Petersburg, Russia
}

BACKGROUND: Garden pea (Pisum sativum L.) possesses the ability to form beneficial symbioses with various soil microorganisms. However, different pea cultivars, genotypes, and lines gain more or less benefit from these interactions, so the trait named "efficiency of interaction with soil microorganisms" (EIBSM) was suggested to describe this phenomenon. The molecular mechanisms underlying the manifestation of the EIBSM trait are not properly studied, and only few works focusing on plant responses to combined microbial preparations have been published to date.

METHODS: Eight pea lines previously described as contrasting in manifestation of the EIBSM trait were grown in pots with soil under combined inoculation with nodule bacteria and arbuscular mycorrhizal fungi, and the transcriptome profiles of the whole root systems of the plants were investigated using 3'MACE RNA sequencing.

RESULTS: The relatedness of the lines inferred from the analysis of transcripts' SNVs (Single Nucleotide Variants) corresponded to the manifestation of the EIBSM trait: three high-EIBSM lines and three low-EIBSM lines formed two distinct clusters. Thus, the gene expression profiles were compared between these two clusters, which enabled identification of transcriptome signatures characteristic for each group. The lines previously described as high-EIBSM have lower symbiotic activity, and the expression levels of pathogen response genes were elevated compared to the lines with low EIBSM.

CONCLUSION: This result suggests that the mechanism of high interaction efficiency may be connected to stricter host control of symbionts, allowing such plants to expend less on the symbioses.

Keywords: transcriptomics; Pisum sativum L.; nodule bacteria; arbuscular mycorrhiza; effectiveness of symbiosis.

To cite this article:

Afonin AM, Gribchenko ES, Zorin EA, Sulima AS, Romanyuk DA, Zhernakov Al, Shtark OYu, Akhtemova GA, Zhukov VA. Unique transcriptome features of pea (Pisum sativum L.) lines with differing responses to beneficial soil microorganisms. Ecological genetics. 2021;19(2):131-141. DOI: https://doi.org/10.17816/ecogen54703 
DOI: https://doi.org/10.17816/ecogen54703

\title{
Уникальные характеристики транскриптомов линий гороха (Pisum sativum L.), контрастных по эффективности взаимодействий с почвенными микроорганизмами
}

\author{
(C) А.М. Афонин, Э.С. Грибченко, Е.А. Зорин, А.С. Сулима, Д.А. Романюк, А.И. Жернаков, \\ О.Ю. Штарк, Г.А. Ахтемова, В.А. Жуков
}

Всероссийский научно-исследовательский институт сельскохозяйственной микробиологии, Пушкин, Санкт-Петербург, Россия

Горох посевной (Pisum sativum L.) способен образовывать симбиозы с почвенными организмами. Для различных сортов, генотипов и линий гороха польза от таких взаимодействия может значительно отличаться, поэтому был предложен термин «эффективность взаимодействия с полезными почвенными микроорганизмами» (ЭВППМ). Молекулярные основы данного признака исследованы недостаточно, и лишь малое число работ было посвящено ответу растения на комбинированные микробные препараты. В работе были использованы восемь линий гороха посевного, отличающихся по признаку ЭВППМ, которые выращивались в сосудах с почвой при инокуляции клубеньковыми бактериями и арбускулярно-микоризными грибами. Транскриптомные профили их корневых систем были исследованы с использованием метода 3'МАСЕ РНК-секвенирования. Степень родства изучаемых линий была определена путем анализа однонуклеотидных вариантов (SNV - Single Nucleotide Variants), три линии с высоким и три с низким показателем ЭВППМ сформировали два хорошо различимых кластера. Экспрессия генов сравнивалась между этими двумя кластерами, что позволило идентифицировать маркерные транскрипты в обеих группах. В группе с высокой ЭВППМ была значительно снижена экспрессия генов, отвечающих за активность симбиоза, а экспрессия генов, связанных с ответом на патогены, была повышена, по сравнению с группой с низкой ЭВППМ. Этот результат указывает на то, что высокая ЭВППМ может быть связана с более жестким контролем симбионтов со стороны растения-хозяина, что позволяет растению тратить меньше ресурсов на поддержание микросимбионтов.

Ключевые слова: транскриптомика, Pisum sativum L., клубеньковые бактерии, арбускулярная микориза, эффективность симбиоза.

Как цитировать:

Афонин А.М., Грибченко Э.С., Зорин Е.А., Сулима А.С., Романюк Д.А., Жернаков А.И., Штарк О.Ю., Ахтемова Г.А., Жуков В.А. Уникальные характеристики транскриптомов линий гороха (Pisum sativum L.), контрастных по эффективности взаимодействий с почвенными микроорганизмами // Экологическая генетика. 2021. Т. 19. № 2. С. 131-141. DOI: https://doi.org/10.17816/ecogen54703 


\section{BACKGROUND}

Pea (Pisum sativum L.), like other legumes, forms beneficial symbioses with a wide range of soil microorganisms, including nodule bacteria (rhizobia) and arbuscular-mycorrhizal (AM) fungi [1]. A plant hosts microsymbionts in its tissues and feeds them with photosynthates; rhizobia supply the plant with fixed atmospheric nitrogen, and AM fungi provide water and hardly soluble phosphates [2]. Thus, the genomes of microsymbionts complement the genome of a plant, providing new functions to a newly formed symbiotic system [3].

Pea was domesticated over 10000 years ago [4]. During pea domestication and subsequent selection and breeding, a large number of pea landraces and, later on, varieties and cultivars with highly differing phenotypes came to be (now, the number of pea accessions in seed collections exceeds 70,000 ) [5]. Some specific traits, namely, pod dehiscence and seed dormancy, were lost in domesticated peas [6], when seed number, weight, and taste, along with drought-, insect- and disease tolerance, were improved during domestication and further breeding [7]. However, other qualities, such as symbiotic performance, i.e., the ability to effectively interact with beneficial microorganisms, were not actively selected for, thus, the alleles that confer high symbiotic effectiveness may be lacking in a large proportion of the cultured pea accessions available to researchers and agriculture [6].

The response of pea to inoculation with soil microorganisms has been investigated in various lines and cultivars, under mono-inoculation with either rhizobia or AM fungi, or under complex inoculation with both symbionts [8]. The effect of inoculation in terms of increase in plant and seed biomass was often variable and was dependent on experimental conditions and plant genotype, i.e. some genotypes were shown to be more or less responsive to inoculation. Based on the results of pot and field trials, the trait called EIBSM (for Effectiveness of Interaction with Beneficial Soil Microorganisms), defined as the degree of increase in seed biomass under combined inoculation compared to uninoculated control, was suggested as a prospective trait for pea breeding [9].

In last five years, 'omic' technologies, such as proteomics and metabolomics, have been successfully applied to investigate the molecular bases of pea response to microsymbionts and pathogens [10-13]. It was shown that inoculation with rhizobia and/or AM fungi not only improves plant nutrition and seed filling but also can increase the plant's resistance to the pathogenic fungus Didymella pinodes [10]. Additionally, two different strategies of response to complex inoculation with rhizobia and AM fungi were described for different pea genotypes: under inoculation, the 'responsive' genotype prolonged the seed filling stage, which led to increase in seed biomass, while the 'nonresponsive' genotype, as opposite, shortened the seed maturation period [12].
However, the above-mentioned studies were performed either on a single pea cultivar or on a pair of cultivars, which does not allow general conclusions about the molecular base of the responses to microsymbionts. In the present work, using a modified RNAseq, 3'MACE-seq [14], we analysed the transcriptomes of the whole root systems of eight genotypes previously characterized with respect to EIBSM trait, and described the transcriptome profiles and SNVs (single nucleotide variants) characteristic for 'high-EIBSM' genotypes in contrast to 'low-EIBSM' ones.

\section{MATERIALS AND METHODS}

\section{Plant material}

The pea lines used for the experiment were chosen based on their EIBSM manifestation, according to [8] (the low- or high-EIBSM labels were designated based on the results of three-year field trials, 2002-2004, Orel region, Russia). The line k-3064 was obtained from the collection of cultivated peas of the N.I. Vavilov All-Russian Institute of Plant Genetic Resources (VIR), Saint Petersburg, Russia. All other lines originated from the center for Grain Legume Genetics Physiology Research: Pullman, Department of Agriculture, Washington University, USA. The lines were propagated in All-Russia Research Institute for Agricultural Microbiology (Saint Petersburg, Russia). The lines and their phenotype are listed in Table 1.

\section{AM inoculum preparation}

The AM inoculum consisted of three $R$. irregularis strains BEG144, BEG53 (both provided by the International Bank for the Glomeromycota, Dijon, France), and ST3 (All-Russia Research Institute for Agricultural Microbiology, Saint Petersburg) [15]. All isolates were cultured individually in a sand/soil mixture (1:1 v/v) using Plectranthus australis $\mathrm{R}$. Br. as a host plant. To obtain the inoculum of AM fungi, the seeds of sorghum (Sorghum sp.) were surface sterilized with a $0.15 \%(\mathrm{w} / \mathrm{v})$ aqueous solution of potassium permanganate for $15 \mathrm{~min}$, and transferred to pots, filled with a soil-based substrate $(\mathrm{pH} 7)$ containing dried $P$. australis roots colonized with the three above mentioned $R$. irregularis strains. After about 120 days of

Table 1. The pea lines used in this work

\begin{tabular}{ll}
\hline \multicolumn{1}{c}{ Line } & Phenotype \\
\hline Lifter & low-EIBSM \\
PS9910134 & low-EIBSM \\
PS9910135 & low-EIBSM \\
PS9910188 & low-EIBSM \\
k-3064 & low-EIBSM \\
PS810240 & high-EIBSM \\
PS610324 & high-EIBSM \\
PS9910029 & high-EIBSM \\
\hline
\end{tabular}

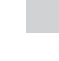


vegetation, the colonized sorghum roots were separated from the substrate, cut into $1 \mathrm{~cm}$ pieces, dried and mixed with the substrate to establish the inoculum.

\section{Plant growth conditions}

The seeds were surface sterilized with concentrated sulfuric acid, rinsed with sterile water, germinated on $1 \%$ agaragar medium for three days in darkness at $25^{\circ} \mathrm{C}$. Seeds were planted in $5 \mathrm{~L}$ pots filled with sod-podzolic light loamy soil (five plants per pot), and inoculated with $150 \mathrm{ml}$ of water suspension ( $\left.10^{6} \mathrm{CFU} * \mathrm{l}-1\right)$ of symbiotic bacteria (Rhizobium leguminosarum bv. viciae RCAM1026) [16] in combination with prepared inoculum (see previous section), as described in [17]. After that, each of the 5 planted seeds were covered with $9 \mathrm{~g}$ of the AM fungal inoculum (see previous section). Before planting, the pots were adjusted to the same weight with soil. The plants were grown under noncontrolled light and temperature conditions in the vegetation house of the All-Russia Research Institute for Agricultural Microbiology, Saint Petersburg (June-August 2016). For the RNA isolation and MACE library preparation plants were harvested at 4 weeks after inoculation. For evaluation of the growth parameters the plants were harvested at the mature seed stage ( 3 months after planting). Data processing and statistical evaluation was performed in the $R$ environment [18]. No significant changes in seed weight or whole plant weight were observed.

RNA extraction, library preparation and sequencing

The root systems of the plants at 4 weeks after inoculation were extracted from soil, the substrate was washed away with running water, and then the roots were snapfrozen in liquid nitrogen. The material was ground using mortar and pestle, the RNA was isolated using the Trizol reagent (Thermo Fisher Scientific, USA) according to the manufacturer's protocol with minor changes. The RNA quality was assessed visually using gel electrophoresis in $1.5 \%$ agarose, and the concentration of RNA was measured using a Qubit Fluorometer and Qubit RNA BR Assay Kit
(Thermo Fisher Scientific, USA). The MACE library preparation using the MACE kit v 1.0 and library sequencing on an Illumina HiSeq2000 platform were performed by GenXPro GmbH (Frankfurt am Main, Germany).

\section{Bioinformatic analysis}

The FastQC (version 0.11.8) and multiqc [19] were used to assess the quality of raw reads. Adapters, low quality reads, human and bacterial contaminants were removed as in [20]. Paired-end reads were mapped to the reference genome of the cv. Caméor [21] and gene expression was measured using STAR (version 2.7.3a.) [22] with the -quantMode GeneCounts option enabled. Differential gene expression analysis was performed using the DESeq2 [23] package in the R environment. Mercator online tool [24] was used to assign functional categories to the differentially expressed genes.

To analyze the SNP distribution in the pea lines, the reads were mapped against the reference using the bwa algorithm. The resulting bam files were used for variant calling using the deepvariant pipeline [25]. All the generated gvcf files were combined using the GLnexus pipeline into a single VCF file [26]. The VCF file manipulations were performed in the $\mathrm{R}$ environment with the vcfR and adegenet packages $[27,28]$.

\section{Data availability}

The sequence data have been uploaded to the NCBI database. The BioProject number is PRJNA685796, raw Illumina data has the following SRA accession numbers SRR13260340-SRR13260347.

\section{RESULTS AND DISCUSSION}

\section{Analysis of SNV profiles for the lines}

Since the 3'MACE-seq enables both precise gene expression level and SNV analysis [14], the genetic relatedness of the lines was estimated first. On the base of all the SNVs found by mapping of reads to the pea genome, a genetic distance tree was built (Fig. 1).

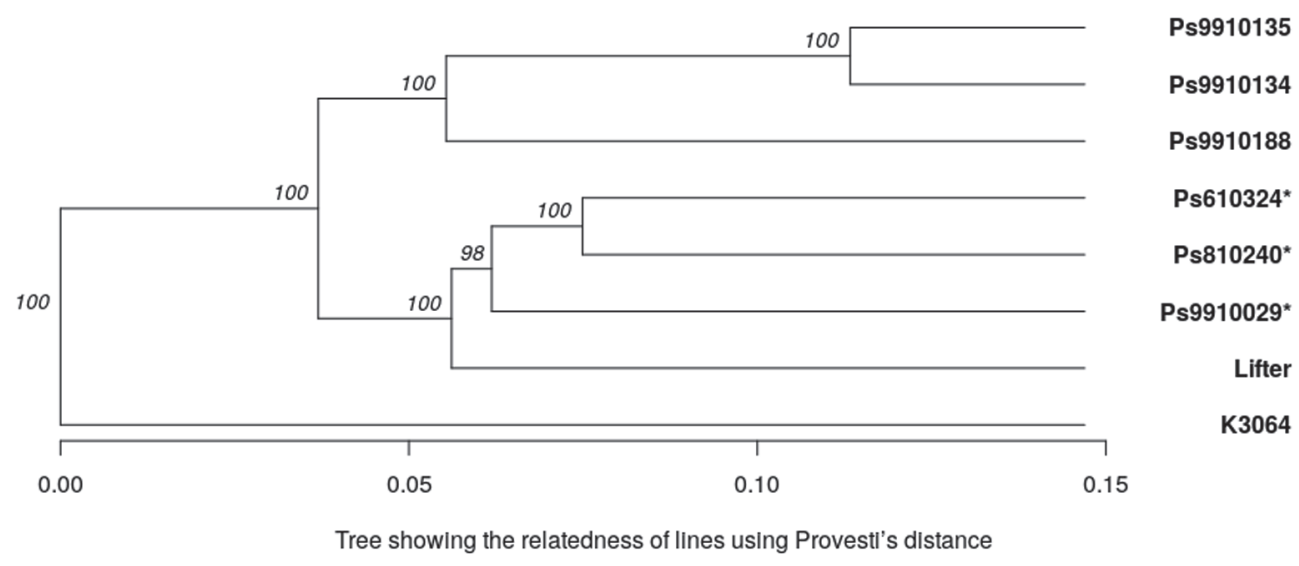

Fig. 1. The tree shows the genetic relatedness of pea lines. The distance was calculated using Provesti's distance algorithm of the poppr [28], the bootstrap values are presented in the nodes of the tree. The high-EIBSM lines are denoted with “*” 
As can be seen in Figure 1, the 'high-EIBSM' lines formed a well-defined group. Three lines with low EIBSM, 'Ps9910188', 'Ps9910134' and 'Ps9910135', also formed a cluster, whereas two other lines, 'Lifter' and 'k-3064', were not in either of the groups. Since the manifestation of the EIBSM trait might be determined by different mechanisms in nonrelated genotypes, only two groups were analysed further. Hereinafter, the 'high-EIBSM' and the 'low-EIBSM' characteristics refers to the groups of three genotypes.

No nonsense or missense mutations were found during the SNV analysis in either of the 8 lines, which can be in part explained by the fact that the MACE reads are synthesised mainly on the 3' end on the mRNA molecule, so a good portion of them lie outside of the coding sequence, thus making any nucleotide change not influence the coding capability of the transcripts.

\section{Analysis of transcriptome profiles of the lines}

STAR algorithm was used to map and quantify the reads, the sequencing and mapping results are presented in Table 2.
The transcriptome analysis was performed using the DegSeq2 package. To verify the expression uniformity and for quality control, PCA was performed for the samples in the two groups. The results for the PCA are presented in the Fig. 2.

The two groups are distinctly visible on this graph, as 58 percent of the variance is explained by the first component. It was decided to perform differential gene expression analysis treating each three lines of a single phenotype as a group for differential gene expression. The expression of genes, associated with symbiotic processes, i.e., mycorrhizal and nodule symbiosis formation, was investigated to determine the symbiotic status of the contrasting lines. Six of these genes (Vacuolar iron transporter homolog 4, Early nodulin-12B, Nodulin-1, Early nodulin-16, Probable 2-isopropylmalate synthase, Early nodulin-5), were significantly (Padj $<0,05$ ) downregulated in the high-EIBSM group. That might be the evidence of the less developed nodule symbiosis in the "high-EIBSM" plants.

Table 2. The results of sequencing and read mapping

\begin{tabular}{lccc}
\hline \multicolumn{1}{c}{ Line } & Number of reads, mln & Aligned, $\%$ & Length, bp \\
\hline Ps9910029 & 8.7 & 72.9 & 66 \\
Ps810240 & 7.1 & 67.8 & 66 \\
Ps610324 & 8.4 & 67.7 & 66 \\
Lifter & 7.7 & 62.9 & 66 \\
Ps9910188 & 6.4 & 62.6 & 66 \\
Ps9910134 & 8.3 & 64.2 & 66 \\
Ps9910135 & 16.0 & 73.0 & 66 \\
K-3064 & 14.5 & 69.8 & 66 \\
\hline
\end{tabular}

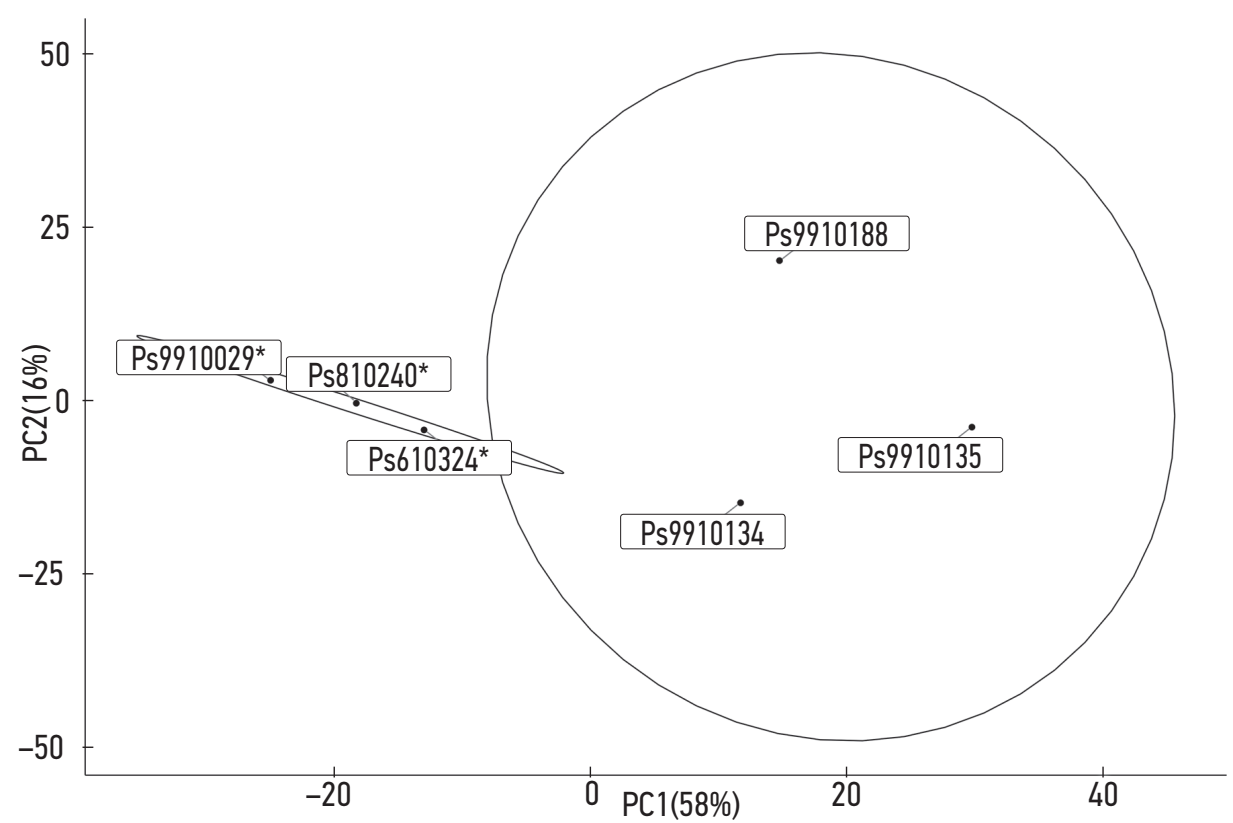

Fig. 2. The PCA plot for the six lines with contrast manifestation of the EIBSM trait. The high-EIBSM lines are denoted with "*”, 95\% confidence ellipses were built for the two discussed groups 


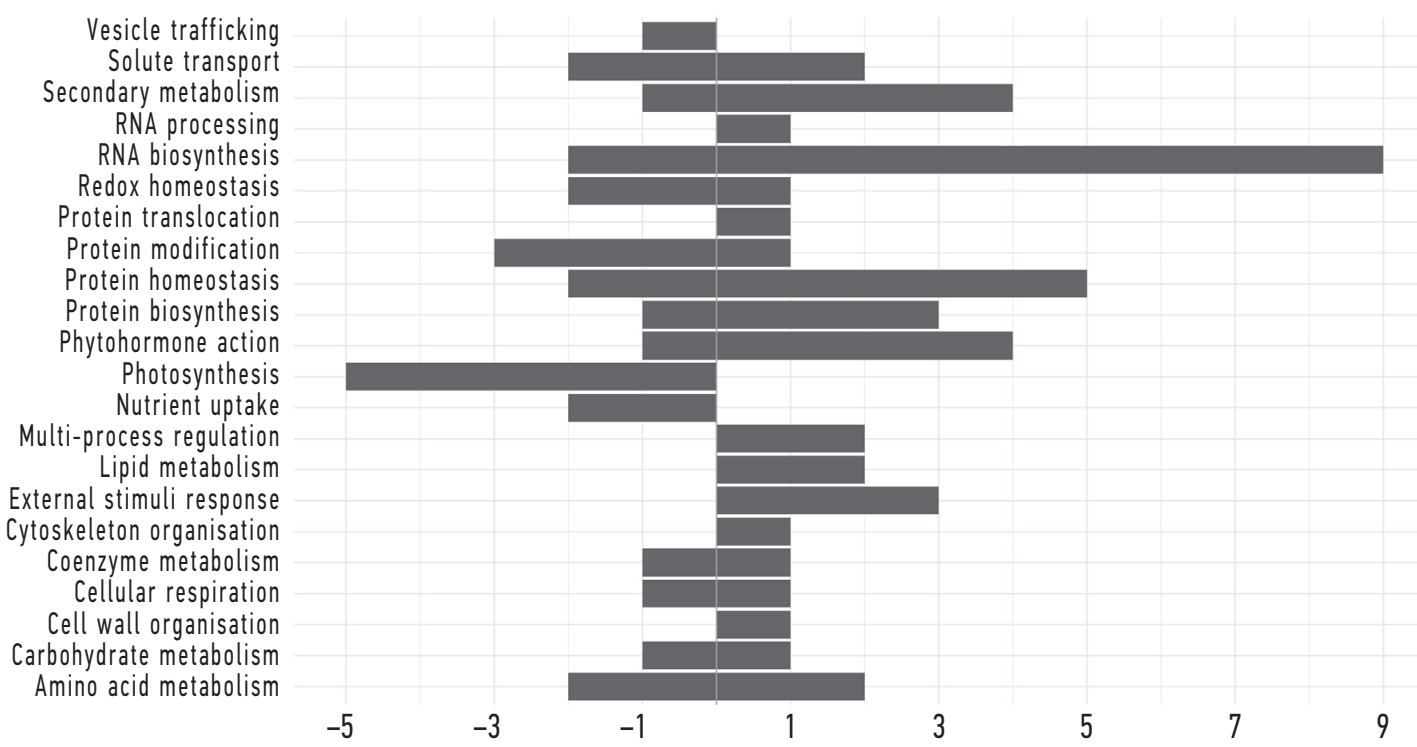

Fig. 3. The functional categories of genes, differing in their expression in EIBSM-contrasting lines. The bars represent the number of genes in the category, the bars to the right are genes with higher expression level in the 'high-EIBSM' lines, and vice versa

A total of 456 genes had significantly (Padj < 0.05) different expression levels between the two investigated groups. Of these, 180 genes were up-regulated, while 276 were down-regulated in the 'high-EIBSM' lines compared to the 'low-EIBSM' ones. For 161 genes, we were able to obtain the Mercator annotation (Fig. 3). As can be seen, in the 'highEIBSM' lines, the vesicle transport genes, the nutrient uptake genes, and genes annotated as related to photosynthesis, are down-regulated, while multiple phytohormone-associated genes, external stimuli response genes, lipid metabolism genes, and RNA and protein biosynthesis genes are upregulated. These genes, whose expression forms specific 'transcriptome signatures' characteristic for 'high-EIBSM' lines, can be considered important for the effective realization of the symbiotic strategy. The full list of differentially expressed genes can be found at http://cloud.arriam.ru/s/ ksQx4dr9ydRsXQo.

The detailed analysis of the differentially expressed genes led us to some preliminary conclusions and speculations on the molecular mechanisms of symbiotic efficiency in the investigated pea lines. As presented in Table 3, 'high-EIBSM' lines show down-regulation of the gene encoding thioredoxin, the ortholog of which is highly active in the nodules of Medicago truncatula Gaertn. plants [30].
The next gene strongly down-regulated in 'high-EIBSM' lines is $M S B P 1$, which appears to be a potential marker of effective mycorrhizal symbiosis. The orthologous gene in M. truncatula (MtMSBP1) encodes a membrane-bound steroid-binding protein, probably involved in brassinosteroid signaling [31]. Interestingly, overexpression of the tomato (Solanum lycopersicum L.) gene SIMSBP1 in transgenic tobacco (Nicotiana tabacum L.) plants resulted in a decrease in biomass development after mycorrhization of the corresponding transgenic lines [32], which is in agreement with low-responsivity to double inoculation of the pea lines with higher MSBPI expression level. Two other down-regulated genes in "highEIBSM' lines encode plastid products (components of light harvesting complexes), and their expression level may reflect a reduced activity of plastids in the roots. The same effect, i.e., a decreased expression level in 'high-EIBSM' lines, was recorded for the plastidial glutamine synthetase (GLN2) gene $[33,34]$. Finally, the down-regulation in 'high-EIBSM' lines was shown for the phytoene synthase (PSY3) gene, which encodes the enzyme catalyzing the rate-limiting step of carotenoid biosynthesis [35]. Carotenoid biosynthesis also occurs in plastids, and in roots, it leads to the production of strigolactones - the signal molecules that promote root colonization by AM fungi [36]. Thus, down-regulation of this

Table 3. Genes differentially expressed between the two ElBSM groups involved in symbiotic processes. The M. truncatula gene IDs are presented according to [37]

\begin{tabular}{|c|c|c|c|c|}
\hline Gene & $\begin{array}{l}\text { Orthologous gene } \\
\text { in M. truncatula }\end{array}$ & $\begin{array}{c}\log 2 \text { Fold- } \\
\text { Change }\end{array}$ & Probable role in symbioses & References \\
\hline M-type thioredoxin & Medtr2g079400.1 & -7.05 & $\begin{array}{c}\text { Control regulation of bacteroid } \\
\text { differentiation in symbiotic } \\
\text { nodules }\end{array}$ & [30] \\
\hline $\begin{array}{l}\text { Membrane steroid-binding } \\
\text { protein } 1 \text { (MSBP1) }\end{array}$ & Medtr1g100727.1 & -3.17 & $\begin{array}{l}\text { Negative regulation of brassino- } \\
\text { steroid signaling; sterol homeosta- } \\
\text { sis in mycorrhized roots }\end{array}$ & {$[31,32]$} \\
\hline
\end{tabular}


Table 3. (Continued)

\begin{tabular}{|c|c|c|c|c|}
\hline Gene & $\begin{array}{l}\text { Orthologous gene } \\
\text { in M. truncatula }\end{array}$ & $\begin{array}{l}\log 2 \text { Fold- } \\
\text { Change }\end{array}$ & Probable role in symbioses & References \\
\hline $\begin{array}{l}\text { Component } L H C b 1 / 2 / 3 \text { of } \\
L H C-I / \text { complex }\end{array}$ & Medtr4g094605.1 & -3.14 & $\begin{array}{l}\text { Unknown; possible role in plastid } \\
\text { functioning in roots }\end{array}$ & [38] \\
\hline $\begin{array}{l}\text { Component } L H C a 3 \text { of } L H C-I \\
\text { complex }\end{array}$ & Medtr5g098785.1 & -2.38 & $\begin{array}{l}\text { Unknown; possible role in plastid } \\
\text { functioning in roots }\end{array}$ & [38] \\
\hline Phytoene synthase (PSY3) & Medtr5g076620.1 & -1.53 & $\begin{array}{c}\text { Catalysis of the first committed } \\
\text { and rate-limiting step in carotenoid } \\
\text { biosynthesis leads to production of } \\
\text { strigolactones }\end{array}$ & [35] \\
\hline $\begin{array}{l}\text { Plastidial glutamine } \\
\text { synthetase (GLN2) }\end{array}$ & Medtr2g021255.1 & -0.93 & $\begin{array}{l}\text { Carbon metabolism and/or nitrogen } \\
\text { assimilation in symbiotic nodules }\end{array}$ & {$[33,34]$} \\
\hline $\begin{array}{l}\text { SMXL strigolactone signal } \\
\text { transducer }\end{array}$ & Medtr4g129230.1 & 0.99 & $\begin{array}{l}\text { Suppressor in strigolactone } \\
\text { signaling }\end{array}$ & [39] \\
\hline $\begin{array}{l}\text { Phosphocholine } \\
\text { phosphatase }\end{array}$ & Medtr8g015960.1 & 1.31 & $\begin{array}{l}\text { Lipid metabolism in mycorrhizal } \\
\text { roots }\end{array}$ & {$[40,41]$} \\
\hline $\begin{array}{l}\text { Phenylalanine ammonia } \\
\text { lyase (PAL) }\end{array}$ & Medtrlg094780.1 & 2.05 & $\begin{array}{l}\text { Flavonoid biosynthesis in roots; } \\
\text { possible inhibition of hyphae growth }\end{array}$ & [42] \\
\hline $\begin{array}{l}\text { 4-coumarate: CoA ligase } \\
(4 C L)\end{array}$ & Medtr5g007640.1 & 2.66 & $\begin{array}{c}\text { Flavonoid biosynthesis in roots; } \\
\text { possible inhibition of hyphae growth }\end{array}$ & \\
\hline Contact site protein (VAP27) & Medtr4g027050.1 & 2.72 & $\begin{array}{l}\text { Possible role in functional arbuscule } \\
\text { development }\end{array}$ & {$[43,44]$} \\
\hline Chalcone synthase (CHS) & Medtr5g007713.1 & 3.26 & $\begin{array}{c}\text { Flavonoid biosynthesis in roots; } \\
\text { possible inhibition of hyphae growth }\end{array}$ & [45] \\
\hline $\begin{array}{l}\text { Benzyl alcohol } \\
\text { 0-benzoyltransferase }\end{array}$ & Medtr0042s0230.1 & 6.46 & $\begin{array}{l}\text { Flavonoid biosynthesis in roots; } \\
\text { possible inhibition of hyphae growth }\end{array}$ & [44] \\
\hline
\end{tabular}

gene in 'high-EIBSM' lines points towards the advantage of plant control of AM fungi spreading over the plant roots.

Some genes were also found to be up-regulated in roots of 'high-EIBSM' lines. Among them is the gene SMXL encoding a suppressor of strigolactone signaling [39], which is in line with down-regulated strigolactone biosynthesis characteristic for 'high-EIBSM' lines. Two genes related to mycorrhization were also found to be up-regulated in "highEIBSM' lines: the gene encoding phosphocholine phosphatase (probably involved in lipid metabolism that is necessary for AM functioning) and the gene encoding the contact site protein VAP27 (probably participating in membrane structure development during arbuscule formation) [40, 41, 43, 44]. Finally, as many as 4 genes involved in flavonoid biosynthesis, namely phenylalanine ammonia lyase (PAL), 4-coumarate: CoA ligase (4CL), chalcone synthase (CHS) and Benzyl alcohol 0-benzoyltransferase were found to be up-regulated in roots of 'high-EIBSM' lines. Flavonoids have many functions in roots, as they play a role of signal molecules during the establishment of nitrogen-fixing symbiosis [42] and may also inhibit the growth of fungal hyphae in roots [46]. Since activation of flavonoid biosynthesis may have different outcomes that positively influence plant growth in symbiotic conditions, we can consider the up-regulation of the genes related to flavonoid biosynthesis as an important transcriptome signature inherent to 'high-EIBSM' pea lines. However, further studies are needed to determine the particular role of flavonoid molecules in the efficiency of nitrogen-fixing and AM symbioses.

At least 14 genes encoding transcription factors (TFs) were also identified as up-regulated in the roots of "highEIBSM' lines, including the WRKY33 transcriptional regulator, an important marker of pathogen response in plants [47]. It is tempting to speculate that the TFs may play a key role in the formation of the characteristic transcriptome signatures and thus provide the 'high-EIBSM' phenotypic manifestation. Indeed, since the largest proportion (40\%-80\%) of domestication genes identified so far are transcriptional regulators [48], the TF genes are the primary candidates to be responsible for the quantitative and qualitative differences between pea genotypes using different ecological strategies, namely symbiotic (responsive, or high-EIBSM) and non-symbiotic (nonresponsive, or (ow-EIBSM) strategies of interaction with beneficial soil microorganisms.

\section{CONCLUSION}

In this work, the lines previously described as contrasting regarding the EIBSM trait were investigated using transcriptomic analysis. The analysis showed the relatedness of the lines with contrast manifestation of the EIBSM trait, and allowed to determine the differential expression of genes 
characteristic for 'high-EIBSM' and 'low-EIBSM' pea genotypes. The results show the principal possibility to investigate the gene expression patterns in genetically diverse, but phenotypically homogenous, groups. By doing so, we managed to highlight the genes, differentiating the high- and low-EIBSM lines, that can be potential expression markers of pea responsivity to inoculation with beneficial soil microorganisms. In general, the overall lower expression of symbiotic genes coupled with the elevated signatures of pathogen response can be the evidence of a stricter control of the plant over its microsymbionts.

\section{DISCLAIMERS}

Funding source. The work was supported by the Russian Science Foundation (project No. 16-16-00118).

\section{REFERENCES}

1. Tsyganov VE, Tsyganova AV. Symbiotic Regulatory Genes Controlling Nodule Development in Pisum sativum L. Plants. 2020;9(12):1741. DOI: 10.3390/plants9121741

2. Shtark 0, Provorov N, Mikić A, et al. Legume root symbioses: natural history and prospects for improvement. Ratar i Povrt. 2011;48:291-304. DOI: 10.5937/ratpov1102291S

3. Tikhonovich IA, Andronov EE, Borisov AY, et al. The principle of genome complementarity in the enhancement of plant adaptive capacities. Russ J Genet. 2015;51:831-846. D0I: 10.1134/ S1022795415090124

4. Zohary D, Hopf M. Domestication of Plants in the Old World: The origin and spread of domesticated plants in Southwest Asia, Europe, and the Mediterranean Basin. Published to Oxford Scholarship Online, 2000. Available from: https://oxford.universitypressscholarship. com/view/10.1093/acprof:osobl/9780199549061.001.0001/acprof9780199549061

5. Smýkal P, Coyne CJ, Redden R, et al. Genetic and Genomic Resour. Grain Legume Improvement. Elsevier, 2013. DOI: 10.1016/C2012-0-00217-7

6. Weeden NF. Genetic changes accompanying the domestication of Pisum sativum: is there a common genetic basis to the 'domestication syndrome' for legumes? Ann Bot. 2007;100(5): 1017-1025. DOI: 10.1093/aob/mcm122

7. Smýkal P, Nelson M, Berger J, Von E. Wettberg, The Impact of Genetic Changes during Crop Domestication. Agronomy. 2018;8(7);119. DOI: 10.3390/agronomy8070119

8. Shtark OY, Danilova TN, Naumkina TS, et al. Analysis of Pea (Pisum Sativum L.) Source Material for Breeding of Cultivars with High Symbiotic Potential and Choice of Criteria for Its Evaluation. Ecological genetics. 2006;4(2):22-28. (In Russ.) DOI: 10.17816/ecogen4222-28

9. Shtark OY, Borisov AY, Zhukov VA, Tikhonovich IA. Mutually beneficial legume symbioses with soil microbes and their potential for plant production. Symbiosis. 2012;58:51-62. DOl: 10.1007/s13199-013-0226-2

10. Desalegn G, Turetschek R, Kaul H-P, Wienkoop S. Microbial symbionts affect Pisum sativum proteome and metabolome under Didymella pinodes infection. J Proteomics. 2016;143:173-187. DOI: 10.1016/J.JPROT.2016.03.018

11. Ranjbar Sistani N, Kau H-P, Desalegn G, Wienkoop S. Rhizobium Impacts on Seed Productivity, Quality, and Protection of Pisum sativum upon Disease Stress Caused by Didymella pinodes: Phenotypic, Proteomic, and Metabolomic Traits. Front Plant Sci. 2017;8. DOl: 10.3389/fpls.2017.01961

12. Mamontova T, Afonin AM, Ihling C, et al. Profiling of seed proteome in pea (Pisum Sativum L.) lines characterized with high and low responsivity to combined inoculation with nodule bacteria and arbuscular mycorrhizal fungi. Molecules. 2019;24(8):1603. DOI: 10.3390/molecules24081603

13. Shtark OY, Zhukov VA, Puzanskiy RK, et al. Metabolic alterations in pea leaves during arbuscular mycorrhiza development. PeerJ. 2019. DOI: 10.7717/peerj.7495

14. Zhernakov Al, Shtark OY, Kulaeva OA, et al. Mapping-by-sequencing using NGS-based 3'-MACE-Seq reveals a new mutant allele of the essential nodulation gene Sym33 (IPD3) in pea (Pisum sativum L.). Peer J. 2019;7. DOI: 10.7717/peerj.6662

15. Kozlova N, Strunnikova OK. Production and specificity of polyclonal antibodies against soluble proteins from the arbuscular mycorrhizal fungus Glomus intraradices. Mycorrhiza. 2001;10:301-305. DOI: 10.1007/PL00009999

16. Afonin A, Sulima A, Zhernakov A, Zhukov V. Draft genome of the strain RCAM1026 Rhizobium leguminosarum bv. viciae. Genomics Data. 2017;11:85-86. D0l: 10.1016/j.gdata.2016.12.003

17. Zhukov VA, Shtark 0, Tikhonovich IA. Evaluation of the symbiotic effectiveness of pea (Pisum sativum L.) Genotypes in pot experiment. Agric Biol. 2017;52:607-614. DOI: 10.15389/agrobiology.2017.3.607eng

18. Fehske H, Schneider R, Weiße A. Computational Many-Particle Physics. Springer, Berlin, Heidelber, 2008. D0l: 10.1007/978-3-540-74686-7 19. Ewels $P$, Magnusson M, Lundin S, Käller M. MultiQC: summarize analysis results for multiple tools and samples in a single report. Bioinformatics. 2016;32(19):3047-3048. DOI: 10.1093/bioinformatics/btw354

20. Afonin AM, Leppyanen IV, Kulaeva OA, et al. A high coverage reference transcriptome assembly of pea (Pisum sativum L.) Mycorrhizal roots. Vavilov journal of genetics and breeding. 2020;24(4): 331-339. DOI: 10.18699/VJ20.625

21. Kreplak J, Madoui MA, Cápal $P$, et al. A reference genome for pea provides insight into legume genome evolution. Nat Genet. 2019:51:1411-1422. DOI: 10.1038/s41588-019-0480-1

22. Dobin A, Davis CA, Schlesinger F, et al. STAR: ultrafast universal RNA-seq aligner. Bioinformatics. 2013;29(1):15-21. DOI: 10.1093/bioinformatics/bts635

23. Love Ml, Huber W, Anders S. Moderated estimation of fold change and dispersion for RNA-seq data with DESeq2. Genome Biol. 2014;15:550. DOI:10.1186/s13059-014-0550-8

24. Lohse M, Nagel A, Herter T, et al. Mercator: a fast and simple web server for genome scale functional annotation of plant sequence data. Plant, Cell Environ. 2014;37(5):1250-1258. DOI: 10.1111/pce.12231 
25. Poplin R, Chang PC, Alexander D, et al. A universal snp and smallindel variant caller using deep neural networks. Nat Biotechnol. 2018;36:983-987. DOI: 10.1038/nbt.4235

26. Lin MF, Rodeh O, Penn J, et al. GLnexus: joint variant calling for large cohort sequencing. BioRxiv. 2018:343970. DOI: 10.1101/343970 27. Knaus BJ, Grünwald NJ. VCFR: a package to manipulate and visualize variant call format data in R. Mol Ecol Resour. 2017;17: 44-53. DOI: 10.1111/1755-0998.12549

28. Jombart T. Adegenet: a R package for the multivariate analysis of genetic markers. Bioinformatics. 2008;24(11):1403-1405. DOI: 10.1093/bioinformatics/btn129

29. Kamvar ZN, Brooks JC, Grünwald NJ. Novel R tools for analysis of genome-wide population genetic data with emphasis on clonality. Front Genet. 2015;6. DOI: 10.3389/fgene.2015.00208

30. Ribeiro CW, Baldacci-Cresp F, Pierre 0, Rouhier N. Regulation of Differentiation of Nitrogen-Fixing Bacteria by Microsymbiont Targeting of Plant Thioredoxin s1. Curr Biol. 2017;27(2):250-256. DOI: 10.1016/j.cub.2016.11.013

31. Kuhn H, Küster $H$, Requena N. Membrane steroid-binding protein 1 induced by a diffusible fungal signal is critical for mycorrhization in Medicago truncatula. New Phytol. 2010;185(3):716-733. DOI: 10.1111/j.1469-8137.2009.03116.x

32. von Sivers $L$, Jaspar $H$, Johst $B$, et al. Brassinosteroids Affect the Symbiosis Between the AM Fungus rhizoglomus irregularis and Solanaceous Host Plants. Front Plant Sci. 2019;10:571 DOI: 10.3389/fpls.2019.00571

33. Melo PM, Lima LM, Santos IM, et al. Expression of the plastidlocated glutamine synthetase of Medicago truncatula. Accumulation of the precursor in root nodules reveals an in vivo control at the level of protein import into plastids. Plant Physiol. 2003;132(1):390-399. DOI: 10.1104/pp.102.016675

34. García-Calderón M, Chiurazzi M, Espuny MR, Márquez AJ. Photorespiratory metabolism and nodule function: Behavior of Lotus japonicus mutants deficient in plastid glutamine synthetase. Mol Plant-Microbe Interact. 2012;25(2):211-219. DOI: 10.1094/MPMI-07-11-0200

35. Stauder R, Welsch R, Camagna M, et al. Strigolactone Levels in Dicot Roots Are Determined by an Ancestral Symbiosis-Regulated Clade of the PHYTOENE SYNTHASE Gene Family. Front Plant Sci. 2018;9. DOI: 10.3389/fpls.2018.00255

36. Waters MT, Gutjahr C, Bennett T, Nelson DC. Strigolactone Signaling and Evolution. Annu Rev Plant Biol. 2017;68:291-322. DOI: 10.1146/annurev-arplant-042916-040925

\section{СПИСОК ЛИТЕРАТУРЫ}

1. Tsyganov V.E., Tsyganova A.V. Symbiotic Regulatory Genes Controlling Nodule Development in Pisum sativum L. // Plants. 2020. Vol. 9. No. 12. P. 1741. DOl: 10.3390/plants9121741

2. Shtark 0., Provorov N., Mikić A., et al. Legume root symbioses: natural history and prospects for improvement // Ratar i Povrt. 2011. Vol. 48. P. 291-304. DOI: 10.5937/ratpov1102291S

3. Tikhonovich I.A., Andronov E.E., Borisov A.Y., et al. The principle of genome complementarity in the enhancement of plant adaptive capacities // Russ J Genet. 2015. Vol. 51. P. 831-846. DOl: 10.1134/S1022795415090124 4. Zohary D., Hopf M. Domestication of Plants in the Old World: The origin and spread of domesticated plants in Southwest Asia, Europe,
37. Tang H, Krishnakumar V, Bidwell S, et al. An improved genome release (version Mt4.0) for the model legume Medicago truncatula. BMC Genomics. 2014;15:312. DOI: 10.1186/1471-2164-15-312

38. Klimmek F, Sjödin A, Noutsos C, et al. Abundantly and rarely expressed Lhc protein genes exhibit distinct regulation patterns in plants. Plant Physiol. 2006;140(3);793-804. DOI: 10.1104/pp.105.073304

39. Marzec M. Perception and signaling of strigolactones. Front Plant Sci. 2016;7:1260. D0I: 10.3389/fpls.2016.01260

40. Keymer A, Pimprikar P, Wewer V, et al. Lipid transfer from plants to arbuscular mycorrhiza fungi. Elife. 2017;6. DOI: 10.7554/eLife.29107

41. Bravo A, Brands M, Wewer V, et al. Arbuscular mycorrhizaspecific enzymes FatM and RAM2 fine-tune lipid biosynthesis to promote development of arbuscular mycorrhiza. New Phytol. 2017;214(4):1631-1645. DOl: 10.1111/nph.14533

42. Abdel-Lateif $K$, Bogusz D, Hocher V. The role of flavonoids in the establishment of plant roots endosymbioses with arbuscular mycorrhiza fungi, rhizobia and Frankia bacteria. Plant Signal Behav. 2012;7(6):636-641. DOI: 10.4161/psb.20039

43. Wang P, Hawes C, Hussey PJ. Plant Endoplasmic ReticulumPlasma Membrane Contact Sites. Trends Plant Sci. 2017;22(4): 289-297. DOI: 10.1016/j.tplants.2016.11.008

44. Genre A, Chabaud M, Faccio A, et al. Prepenetration apparatus assembly precedes and predicts the colonization patterns of arbuscular mycorrhizal fungi within the root cortex of both Medicago truncatula and Daucus carota. Plant Cell. 2008;20(5):1407-1420. DOI: 10.1105/tpc.108.059014

45. Dao TTH, Linthorst HJM, Verpoorte R. Chalcone synthase and its functions in plant resistance. Phytochem Rev. 2011;10:397-412. DOI: 10.1007/s11101-011-9211-7

46. Mierziak J, Wojtasik W, Kulma A, et al. 3-Hydroxybutyrate Is Active Compound in Flax that Upregulates Genes Involved in DNA Methylation. Int J Mol Sci. 2020;21(8):2887. DOI: 10.3390/ijms21082887

47. Chen T, Duan L, Zhou B, et al. Interplay of PathogenInduced Defense Responses and Symbiotic Establishment in Medicago truncatula. Front Microbiol. 2017;8:973. DOI: 10.3389/fmicb.2017.00973

48. Lenser $T$, Theißen $G$. Molecular mechanisms involved in convergent crop domestication. Trends Plant Sci. 2013;18(12):704-714. DOI: 10.1016/j.tplants.2013.08.007

and the Mediterranean Basin. Published to Oxford Scholarship Online, 2000. Доступ по ссылке: https://oxford.universitypressscholarship.com/view/10.1093/acprof: osobl/9780199549061.001.0001/ acprof-9780199549061

5. Smýkal P., Coyne C.J., Redden R., et al. Genetic and Genomic Resour. Grain Legume Improvement. Elsevier, 2013. DOI: 10.1016/C2012-0-00217-7

6. Weeden N.F. Genetic changes accompanying the domestication of Pisum sativum: is there a common genetic basis to the 'domestication syndrome' for legumes? // Ann Bot. 2007. Vol. 100. P. No. 5. P. 1017-1025. DOI: 10.1093/aob/mcm 122 
7. Smýkal P., Nelson M., Berger J., Von E. Wettberg, The Impact of Genetic Changes during Crop Domestication // Agronomy. 2018. Vol. 8. No. 7. P. 119. DOI: 10.3390/agronomy8070119

8. Штарк 0.Ю., Данилова Т.Н., Наумкина Т.С., и др. Анализ исходного материала гороха посевного (Pisum sativum L.) Для селекции сортов с высоким симбиотическим потенциалом и выбор параметров для его оценки // Экологическая генетика. 2006. T. 4, № 2. C. 22-28. DOl: 10.17816/ecogen4222-28

9. Shtark O.Y., Borisov A.Y., Zhukov V.A., Tikhonovich I.A. Mutually beneficial legume symbioses with soil microbes and their potential for plant production // Symbiosis. 2012. Vol. 58. P. 51-62. DOI: 10.1007/s13199-013-0226-2

10. Desalegn G., Turetschek R., Kaul H.-P., Wienkoop S. Microbial symbionts affect Pisum sativum proteome and metabolome under Didymella pinodes infection // J Proteomics. 2016. Vol. 143. P. 173-187. DOI: 10.1016/J.JPROT.2016.03.018

11. Ranjbar Sistani N., Kau H.-P., Desalegn G., Wienkoop S. Rhizobium Impacts on Seed Productivity, Quality, and Protection of Pisum sativum upon Disease Stress Caused by Didymella pinodes: Phenotypic, Proteomic, and Metabolomic Traits // Front Plant Sci. 2017. Vol. 8. DOl: 10.3389/fpls.2017.01961

12. Mamontova T., Afonin A.M., Ihling C., et al. Profiling of seed proteome in pea (Pisum sativum L.) lines characterized with high and low responsivity to combined inoculation with nodule bacteria and arbuscular mycorrhizal fungi // Molecules. 2019. Vol. 24. No. 8. P. 1603. DOI: 10.3390/molecules24081603

13. Shtark O.Y., Zhukov V.A., Puzanskiy R.K., et al. Metabolic alterations in pea leaves during arbuscular mycorrhiza development // PeerJ. 2019. DOI: 10.7717/peerj.7495

14. Zhernakov A.I., Shtark O.Y., Kulaeva O.A., et al. Mapping-bysequencing using NGS-based 3'-MACE-Seq reveals a new mutant allele of the essential nodulation gene Sym33 (IPD3) in pea (Pisum sativum L.) // Peer J. 2019. Vol. 7. DOI: 10.7717/peerj.6662 15. Kozlova N., Strunnikova O.K. Production and specificity of polyclonal antibodies against soluble proteins from the arbuscular mycorrhizal fungus Glomus intraradices // Mycorrhiza. 2001. Vol. 10. P. 301-305. DOI: 10.1007/PL00009999

16. Afonin A., Sulima A., Zhernakov A., Zhukov V. Draft genome of the strain RCAM1026 Rhizobium leguminosarum bv. viciae // Genomics Data. 2017. Vol. 11. P. 85-86. DOl: 10.1016/j.gdata.2016.12.003

17. Zhukov V.A., Shtark O., Tikhonovich I.A. Evaluation of the symbiotic effectiveness of pea (Pisum sativum L.) genotypes in pot experiment // Agric Biol. 2017. Vol. 52. P. 607-614. DOI: 10.15389/agrobiology.2017.3.607eng

18. Fehske H., Schneider R., Weiße A. Computational Many-Particle Physics. Springer, Berlin, Heidelber, 2008. DOl: 10.1007/978-3-540-74686-7 19. Ewels P., Magnusson M., Lundin S., Käller M. MultiQC: summarize analysis results for multiple tools and samples in a single report // Bioinformatics. 2016. Vol. 32. No. 19. P. 3047-3048. DOI: 10.1093/bioinformatics/btw354

20. Афонин А.М., Леппянен И.В., Кулаева О.А., и др. Референсный транскриптом микоризованных корней гороха посевного (Pisum sativum L.) с высоким покрытием // Вавиловский журнал генетики и селекции. 2020. Т. 24, № 4. С. 331-339. DOI: 10.18699/VJ20.625

21. Kreplak J., Madoui M.A., Cápal $P$, et al. A reference genome for pea provides insight into legume genome evolution // Nat Genet. 2019. Vol. 51. P. 1411-1422. DOI: 10.1038/s41588-019-0480-1
22. Dobin A., Davis C.A., Schlesinger F., et al. STAR: ultrafast universal RNA-seq aligner // Bioinformatics. 2013. Vol. 29. No. 1. P. 15-21. DOI: 10.1093/bioinformatics/bts635

23. Love M.I., Huber W., Anders S. Moderated estimation of fold change and dispersion for RNA-seq data with DESeq2 // Genome Biol. 2014. Vol. 15. ID550. DOI:10.1186/s13059-014-0550-8

24. Lohse M., Nagel A., Herter T., et al. Mercator: a fast and simple web server for genome scale functional annotation of plant sequence data // Plant, Cell Environ. 2014. Vol. 37. No. 5. P. 1250-1258. DOI: 10.1111/pce.12231

25. Poplin R., Chang P.C., Alexander D., et al. A universal snp and small-indel variant caller using deep neural networks // Nat Biotechnol. 2018. Vol. 36. P. 983-987. DOI: 10.1038/nbt.4235

26. Lin M.F., Rodeh O., Penn J., et al. GLnexus: joint variant calling for large cohort sequencing // BioRxiv. 2018. ID343970. DOl: 10.1101/343970

27. Knaus B.J., Grünwald N.J. VCFR: a package to manipulate and visualize variant call format data in R // Mol Ecol Resour. 2017. Vol. 17. P. 44-53. DOI: 10.1111/1755-0998.12549

28. Jombart T. adegenet: a R package for the multivariate analysis of genetic markers // Bioinformatics. 2008. Vol. 24. No. 11. P. 1403-1405. DOI: 10.1093/bioinformatics/btn129

29. Kamvar Z.N., Brooks J.C., Grünwald N.J. Novel R tools for analysis of genome-wide population genetic data with emphasis on clonality // Front Genet. 2015. Vol. 6. DOI: 10.3389/fgene.2015.00208

30. Ribeiro C.W., Baldacci-Cresp F., Pierre O., Rouhier N. Regulation of Differentiation of Nitrogen-Fixing Bacteria by Microsymbiont Targeting of Plant Thioredoxin s1 // Curr Biol. 2017. Vol. 27. No. 2. P. 250-256. DOl: 10.1016/j.cub.2016.11.013

31. Kuhn H., Küster H., Requena N. Membrane steroid-binding protein 1 induced by a diffusible fungal signal is critical for mycorrhization in Medicago truncatula // New Phytol. 2010. Vol. 185. No. 3. P. 716-733. DOl: 10.1111/j.1469-8137.2009.03116.x

32. von Sivers L., Jaspar H., Johst B., et al. Brassinosteroids Affect the Symbiosis Between the AM Fungus Rhizoglomus irregularis and Solanaceous Host Plants // Front Plant Sci. 2019. Vol. 10. P. 571. DOI: 10.3389/fpls.2019.00571

33. Melo P.M., Lima L.M., Santos I.M., et al. Expression of the plastid-located glutamine synthetase of Medicago truncatula. Accumulation of the precursor in root nodules reveals an in vivo control at the level of protein import into plastids // Plant Physiol. 2003. Vol. 132. No. 1. P. 390-399. DOI: 10.1104/pp.102.016675

34. García-Calderón M., Chiurazzi M., Espuny M.R., Márquez A.J. Photorespiratory metabolism and nodule function: Behavior of Lotus japonicus mutants deficient in plastid glutamine synthetase // Mol Plant-Microbe Interact. 2012. Vol. 25. No. 2. P. 211-219. DOI: 10.1094/MPMI-07-11-0200

35. Stauder R., Welsch R., Camagna M., et al. Strigolactone Levels in Dicot Roots Are Determined by an Ancestral Symbiosis-Regulated Clade of the PHYTOENE SYNTHASE Gene Family // Front Plant Sci. 2018. Vol. 9. DOI: 10.3389/fpls.2018.00255

36. Waters M.T., Gutjahr C., Bennett T., Nelson D.C. Strigolactone Signaling and Evolution // Annu Rev Plant Biol. 2017. Vol. 68. P. 291-322. DOI: 10.1146/annurev-arplant-042916-040925

37. Tang H., Krishnakumar V., Bidwell S., et al. An improved genome release (version Mt4.0) for the model legume Medicago truncatula // BMC Genomics. 2014. Vol. 15. ID312. DOI: 10.1186/1471-2164-15-312 
38. Klimmek F., Sjödin A., Noutsos C., et al. Abundantly and rarely expressed Lhc protein genes exhibit distinct regulation patterns in plants // Plant Physiol. 2006. Vol. 140. No. 3. P. 793-804. DOI: 10.1104/pp.105.073304

39. Marzec M. Perception and signaling of strigolactones // Front Plant Sci. 2016. Vol. 7. ID1260. D0I: 10.3389/fpls.2016.01260

40. Keymer A., Pimprikar P., Wewer V., et al. Lipid transfer from plants to arbuscular mycorrhiza fungi // Elife. 2017. Vol. 6. DOI: 10.7554/eLife.29107

41. Bravo A., Brands M., Wewer V., et al. Arbuscular mycorrhizaspecific enzymes FatM and RAM2 fine-tune lipid biosynthesis to promote development of arbuscular mycorrhiza // New Phytol. 2017. Vol. 214. No. 4. P. 1631-1645. DOl: 10.1111/nph.14533

42. Abdel-Lateif K., Bogusz D., Hocher V. The role of flavonoids in the establishment of plant roots endosymbioses with arbuscular mycorrhiza fungi, rhizobia and Frankia bacteria // Plant Signal Behav. 2012. Vol. 7. No. 6. P. 636-641. D0I: 10.4161/psb.20039

43. Wang P., Hawes C., Hussey P.J. Plant Endoplasmic ReticulumPlasma Membrane Contact Sites // Trends Plant Sci. 2017. Vol. 22. No. 4. P. 289-297. DOI: 10.1016/j.tplants.2016.11.008
44. Genre A., Chabaud M., Faccio A., et al. Prepenetration apparatus assembly precedes and predicts the colonization patterns of arbuscular mycorrhizal fungi within the root cortex of both Medicago truncatula and Daucus carota // Plant Cell. 2008. Vol. 20. No. 5. P. 1407-1420. DOI: 10.1105/tpc.108.059014

45. Dao T.T.H., Linthorst H.J.M., Verpoorte R. Chalcone synthase and its functions in plant resistance // Phytochem Rev. 2011. Vol. 10. P. 397-412. DOl: 10.1007/s11101-011-9211-7

46. Mierziak J., Wojtasik W., Kulma A., et al. 3-Hydroxybutyrate Is Active Compound in Flax that Upregulates Genes Involved in DNA Methylation // Int J Mol Sci. 2020. Vol. 21. No. 8. P. 2887. DOI: 10.3390/ijms21082887

47. Chen T., Duan L., Zhou B., et al. Interplay of PathogenInduced Defense Responses and Symbiotic Establishment in Medicago truncatula // Front Microbiol. 2017. Vol. 8. P. 973. DOI: 10.3389/fmicb.2017.00973

48. Lenser T., Theißen G. Molecular mechanisms involved in convergent crop domestication // Trends Plant Sci. 2013. Vol. 18. No. 12. P. 704-714. DOI: 10.1016/j.tplants.2013.08.007

\section{AUTHORS INFO}

*Alexey M. Afonin, Research engineer; address: 3, Podbelsky highway, Pushkin, Saint Petersburg, 196608, Russia;

ORCID: https://orcid.org/0000-0002-8530-0226; e-mail: afoninalexeym@gmail.com.

Emma S. Gribchenko, Technician; ORCID: https://orcid.org/0000-0002-1538-5527; e-mail: gribemma@gmail.com.

Evgeny A. Zorin, Research engineer; ORCID: https://orcid.org/0000-0001-5666-3020; e-mail:kjokkjok8@gmail.com.

Anton S. Sulima, PhD, Cand. Sci. (Biol.); ORCID: https://orcid.org/0000-0002-2300-857X; e-mail: asulima@arriam.ru.

Daria A. Romanyuk, PhD, Cand. Sci. (Biol.); ORCID: https://orcid.org/0000-0001-9576-1256; e-mail: daria-rom@yandex.ru.

Aleksandr I. Zhernakov; ORCID: https://orcid.org/0000-00018961-9317; e-mail: azhernakov@arriam.ru.

Oksana Yu. Shtark, PhD, Cand. Sci. (Biol.); ORCID: https://orcid.org/0000-0002-3656-4559; e-mail: oshtark@arriam.ru.

Gulnar A. Akhtemova, PhD, Cand. Sci. (Biol.); ORCID: https://orcid.org/0000-0001-7957-3693; e-mail: gakhtemova@arriam.ru.

Vladimir A. Zhukov, PhD, Cand. Sci. (Biol.); ORCID: https://orcid.org/0000-0002-2411-9191; e-mail:vzhukov@arriam.ru.

\section{ОБ АВТОРАX}

*Афонин Алексей Михайлович, инженер-исследователь; адрес: Россия, 196608, Санкт-Петербург, г. Пушкин, 8, ш. Подбельского, д. 3; ORCID: https://orcid.org/0000-0002-8530-0226; e-mail: afoninalexeym@gmail.com

Эмма Сергеевна Грибченко, техник; ORCID: https://orcid.org/0000-0002-1538-5527; e-mail: gribemma@gmail.com.

Евгений Андреевич Зорин, инженер-исследователь; ORCID: https://orcid.org/0000-0001-5666-3020; e-mail: kjokkjok8@gmail.com.

Антон Сергеевич Сулима, канд. биол. наук; ORCID: https://orcid.org/0000-0002-2300-857X; e-mail: asulima@arriam.ru.

Дарья Андреевна Романюк, канд. биол. наук; ORCID: https://orcid.org/0000-0001-9576-1256; e-mail: daria-rom@yandex.ru.

Александр Игоревич Жернаков; ORCID: https://orcid. org/0000-0001-8961-9317; e-mail: azhernakov@arriam.ru.

Оксана Юрьевна Штарк, канд. биол. наук; ORCID: https://orcid.org/0000-0002-3656-4559; e-mail: oshtark@arriam.ru.

Гульнар Асановна Ахтемова, канд. биол. наук; ORCID: https://orcid.org/0000-0001-7957-3693; e-mail: gakhtemova@arriam.ru.

Владимир Александрович Жуков, канд. биол. наук; ORCID: https://orcid.org/0000-0002-2411-9191; e-mail:vzhukov@arriam.ru. 